\title{
Water contamination of Moscow's small rivers with different anthropogenic impacts
}

\author{
D. Kramer \& I. Tikhonova \\ Faculty of Biotechnology and Industrial Ecology, Mendeleev University \\ of Chemical Technology of Russia, Russian Federation
}

\begin{abstract}
In 2010-2013 we took out a survey of five of Moscow's small rivers with different levels of anthropogenic impact: Los, Kotlovka, Nischcenka, Businka and Tarakanovka. The first goal of our observation was to determine the level of water pollution in these rivers. To achieve the goal we analyzed water samples for parameters such as $\mathrm{pH}$ value, heavy metal concentrations, dichromate oxidation and others. Also, we calculated such parameters as the water pollution index (WPI) and bottom accumulation coefficient (BAC) for $\mathrm{Zn}$ and $\mathrm{Cu}$, which was calculated using bottom sediment contamination data. The results of our survey showed that the most polluted river is River Tarakanovka, which has a huge anthropogenic impact; the major contaminants being $\mathrm{Fe}, \mathrm{Cu}$ and $\mathrm{Zn}$.

Keywords: small rivers, water pollution, water pollution index, bottom accumulation coefficient.
\end{abstract}

\section{Introduction}

In Moscow's urban territory there are 141 small rivers and streams together with 430 ponds. The largest of them are the rivers Yauza, Shodnya and Setun, which begin in the Moscow region and are tributaries to Moskva River.

Small rivers largely function as regulators of the landscape's water regimes; maintaining the balance and redistribution of moisture. A network of small rivers determines the originality of the physico-chemical composition of water, aquatic ecological communities, hydrological, hydrochemical and hydrobiological regime, as well as the water quality in medium and large rivers. One of the main characteristics of small rivers is the close relationship of their runoff formation with the landscape of the river basin [1]. They are the most vulnerable elements 
of river systems, being the first to respond to human-induced changes that occur in their catchment areas [2].

Nowadays, the majority of Moscow's small rivers are exposed to severe anthropogenic impact. About 90 small rivers of Moscow lie in underground pipes and more than 100 rivers and streams have disappeared over the last century. Only 59 rivers and streams in Moscow flow in an open channel, almost all of them have a huge human impact due to industry and transport [3].

In 2009-2012 we carried out a survey of five of Moscow's small rivers: Los, Kotlovka, Businka, Tarakanovka and Nischcenka. One of the goals was to estimate the water quality in these rivers.

In this work we analysed water samples for such parameters as $\mathrm{pH}$ value, heavy metal concentrations, dichromate oxidation and others, calculated the water pollution index (WPI) [4] as a parameter for water quality and also calculated the bottom accumulation coefficient (BAC) using data for bottom sediment contamination.

\section{Methodology and field observations}

\subsection{Field observations}

The first part of our work was to observe the visual condition of the rivers by photographing the area. Our goal was to carry out a description of the river banks and to identify possible sources of pollutants in the rivers.

River Los flows in the north-east of Moscow, it is the left and largest tributary of the River Ichka. Its length is $4.5 \mathrm{~km}$ and the catchment area is about $8 \mathrm{~km}^{2}$; average water flow is $0.06 \mathrm{~m}^{3} / \mathrm{s}$. River Los is the largest pure natural water body flowing in Moscow, the river basin is almost completely forested and does not intersect with highways. River Los and its tributaries flow entirely within the National Park "Losinyi Ostrov" (Moose Island).

River Kotlovka flows in the south of Moscow, it is the third largest right tributary of the Moskva River, originating in Bitza forest park. The total length of the river is $7.6 \mathrm{~km}, 4.7 \mathrm{~km}$ of which - in the open channel, $2.9 \mathrm{~km}$ - in the sewers. The average water flow is $0.14 \mathrm{~m}^{3} / \mathrm{s}$. The ecological condition of River Kotlovka improved after a series of measures were taken in 2009. According to the data of 2012, water quality in River Kotlovka is estimated as being "conditionally clean" [5].

River Businka is situated in the north of Moscow and Moscow region. The total length of the river is about $4.5 \mathrm{~km}, 1.4 \mathrm{~km}$ of which flows in Moscow (part of the river lies in the collector). The average water flow is $0.5 \mathrm{~m}^{3} / \mathrm{s}$. It is a right tributary to the River Likhoborka, which in turn flows into the River Yauza. Except for short open areas in Korovino and Businovo, the river flows in an underground collector. River Businka is almost entirely contaminated. It takes the discharge from snow melting points, heating stations, illegal dumps and several industrial objects.

River Tarakanovka flows in the west of Moscow, it is a left tributary of the Moskva River. Its total length is $7.8 \mathrm{~km}$ (a large part lies in the collector). The basin area is $18.3 \mathrm{~km}^{2}$ and the average water flow is $0.13 \mathrm{~m}^{3} / \mathrm{s}$. In the $1950 \mathrm{~s}$ and 
1960s of the XXth century the river was almost completely removed to the collector. River Tarakanovka is considered to be one of the most polluted rivers in Moscow. The water at the mouth of the river is estimated as being "contaminated" according to its quality [5]. In the first half of 2013, high concentrations of organic compounds and iron were found in its estuary [6].

River Nischcenka is situated in the south-east of Moscow, it is a left tributary of the Moskva River. The river is about $11 \mathrm{~km}$ long (partially enclosed in a collector). The basin area is $85.7 \mathrm{~km}^{2}$; average water flow is $0.95 \mathrm{~m}^{3} / \mathrm{s}$. The river is used for rafting snow that is removed from the surrounding areas. Nischenka flows in the industrial zone and takes the discharge from several facilities. According to 2008 data, River Nischcenka was considered to be the most polluted river in Moscow [7] although, in 2012, the water quality improved to being "conditionally clean" [5].

\subsection{Sampling operations}

According to the results of our field observation, 9 profiles (sampling points) on the Rivers Los, Businka, Tarakanovka and Nischcenka and 11 profiles on River Kotlovka were chosen. Sampling was carried out during the autumn flood, when the level of water pollution should be maximal for all 5 rivers. Sampling was carried out from rivers' sources to confluence points to other rivers. One sample was taken from each sampling point.

\subsection{Analyzing procedures}

We analyzed such parameters in water samples as:

1. $\mathrm{pH}$ value;

2. Dichromate oxidation;

3. TDU (dry residue);

4. Suspended solids concentration;

5. Chlorides concentration;

6. Content of total Fe;

7. Content of $\mathrm{Cu}$;

8. Content of $\mathrm{Zn}$;

9. Content of Sr.

The parameter list includes several basic hydrochemical parameters ( $\mathrm{pH}, \mathrm{TDU}$, dichromate oxidation, total $\mathrm{Fe}$ and others) and several additional heavy metals as major inorganic pollutants. Heavy metal concentrations ( $\mathrm{Fe}, \mathrm{Cu}, \mathrm{Zn}, \mathrm{Sr}$ ) were measured by atomic absorption spectrometry. All used analytical methods are certified by scientific government organizations.

\section{Results and discussion}

\subsection{Water sample analyses}

To assess the data of water sample analyses, we used the maximum permissible concentrations (MPC) for rivers that are used for fisheries.

The results of water analyses are presented in tables 1-5. 

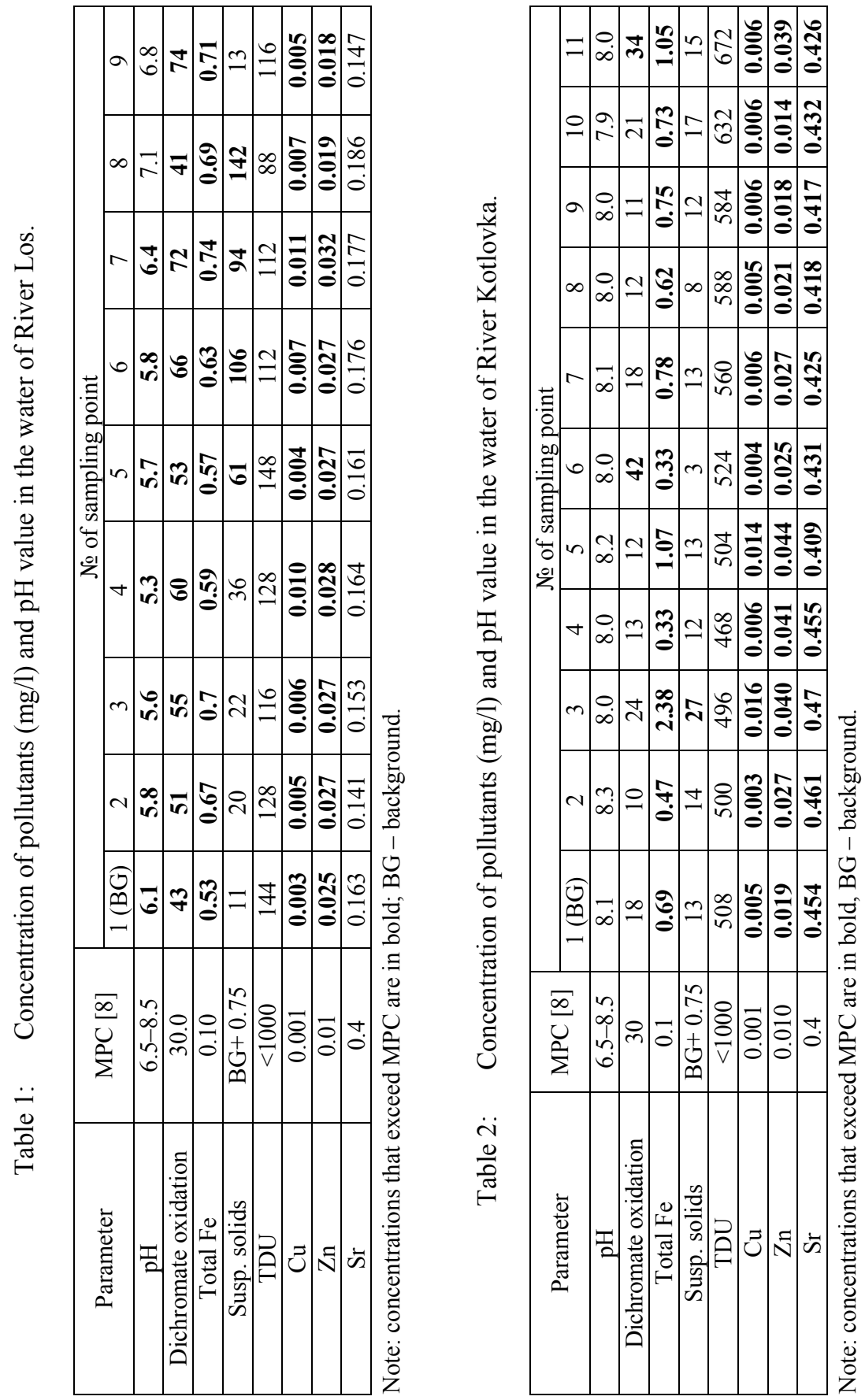

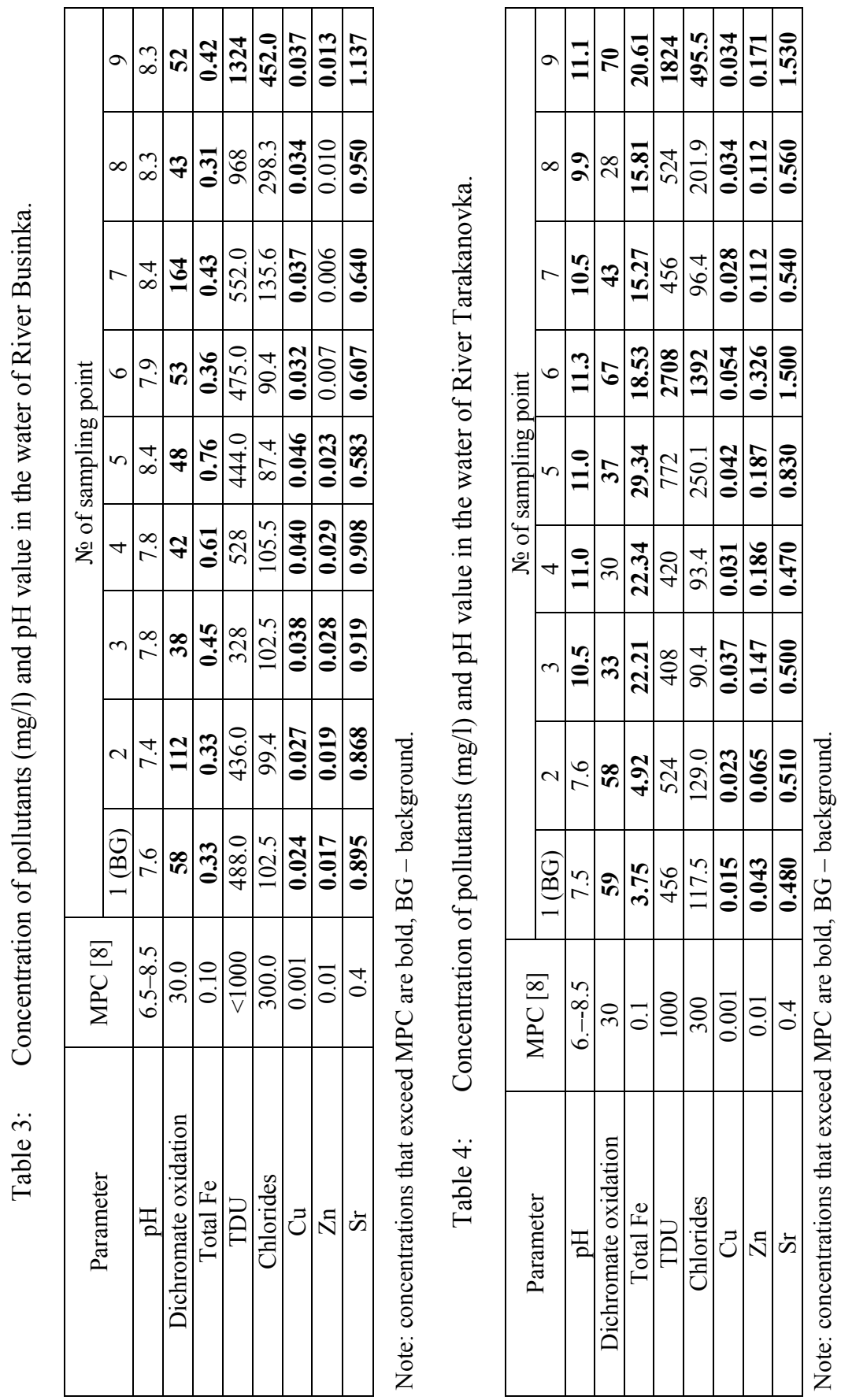


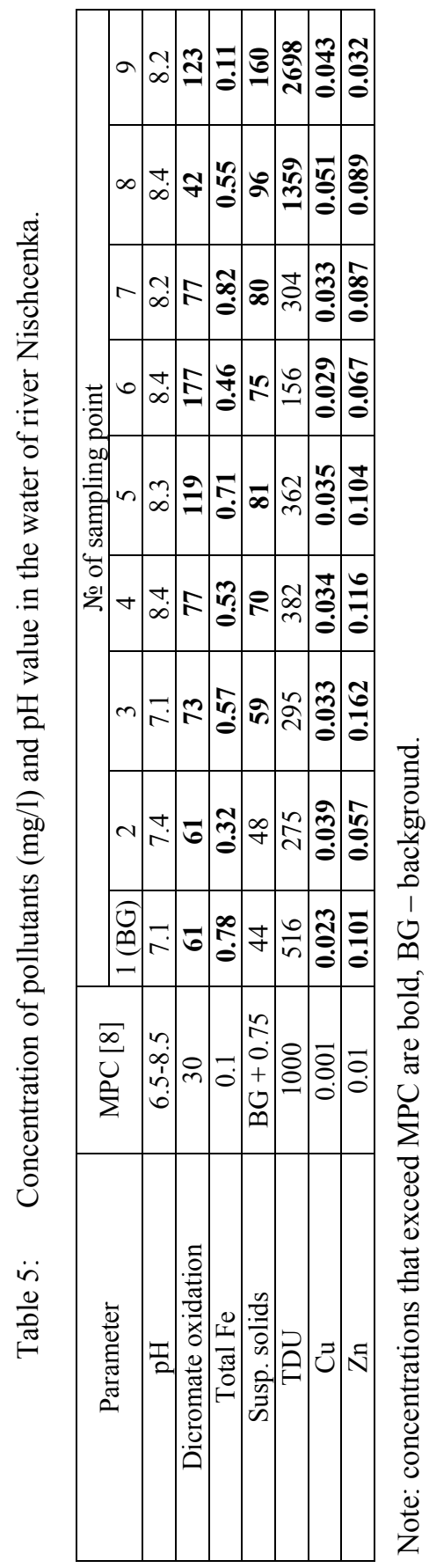


In all the water samples of River Los, there are excesses of MPC for dichromate oxidation; a total of $\mathrm{Fe}, \mathrm{Cu}$ and $\mathrm{Zn}$.

The water of River Kotlovka has excesses of MPC by all measured heavy metals in all sampling points.

The water of River Businka is heavily contaminated by either organic substances or heavy metals, especially by total $\mathrm{Fe}, \mathrm{Cu}$ and $\mathrm{Sr}$, which can be caused by the presence of solid waste landfill in the river basin.

The water of River Tarakanovka is highly contaminated with heavy metals (total $\mathrm{Fe}, \mathrm{Cu}, \mathrm{Zn}$ and $\mathrm{Sr}$ ), which can be caused by pollutants washed off from its garbaged banks and nearby territory; the high content of organic pollution is from the same cause. The most polluted sampling points are № 6 and 9, where we found several culverts.

The water of River Nischcenka is also contaminated by heavy metals (total $\mathrm{Fe}, \mathrm{Cu}$ and $\mathrm{Zn}$ ) and organic substances. There are excesses of MPC for TDU in sampling points № 8 and 9 as well. High level of pollution in river Nischcenka can be explained by the presence of several industrial objects.

The surveyed small rivers of Moscow are highly contaminated with heavy metals (average concentrations of total $\mathrm{Fe}, \mathrm{Zn}$ and $\mathrm{Cu}$ are above MPC in all rivers). The highest concentrations are observed in rivers Businka, Tarakanovka and Nischcenka, which occur in industrial zones. Pollution of rivers by organic compounds is also significant (average concentration of dichromate oxidation value satisfies MPC only in water of river Kotlovka). The most polluted rivers by organic compounds are Businka and Nischcenka.

\subsection{Results of WPI calculation}

WPI was used as a basic characteristic of water quality in our rivers. WPI is calculated by the following formula:

$$
\text { WPI }=\frac{1}{N} \sum_{i=1}^{N} \frac{C i}{M P C i}
$$

where $\mathrm{C}_{\mathrm{i}}$ - concentration of pollutant,

$\mathrm{N}$ - number of parameters used in calculation,

$\mathrm{MPC}_{\mathrm{i}}-\mathrm{MPC}$ for pollutant.

WPI calculation results are presented in table 6 and figure 1.

According to the WPI and literature data [9], the water of Rivers Los and Kotlovka has the water quality class $3 b$ - "very contaminated". The water of River Businka is characterized by the quality class $4 \mathrm{~b}$ - "dirty", the water of River Nischcenka is categorized by the quality class $4 c$ - "very dirty". The most polluted water is in River Tarakanovka. It is characterized by the quality class 5 - "extremely dirty". The major pollutants in this case are heavy metals, namely total $\mathrm{Fe}, \mathrm{Cu}$ and $\mathrm{Zn}$. 
Table 6: WPI in the water samples of Moscow's small rivers.

\begin{tabular}{|c|c|c|c|c|c|}
\hline № of sampling point & Los & Kotlovka & Businka & Nischcenka & Tarakanovka \\
\hline 1 & 1.94 & 2.65 & 4.33 & 7.41 & 7.73 \\
\hline 2 & 2.58 & 2.04 & 5.6 & 8.55 & 10.48 \\
\hline 3 & 2.81 & 7.84 & 7.39 & 9.83 & 34.78 \\
\hline 4 & 3.41 & 2.52 & 7.66 & 9.24 & 34.67 \\
\hline 5 & 2.74 & 5.17 & 9.06 & 9.78 & 45.06 \\
\hline 6 & 3.78 & 1.99 & 5.52 & 8.01 & 35.84 \\
\hline 7 & 4.48 & 3.11 & 7.62 & 9.1 & 24.61 \\
\hline 8 & 4.00 & 2.48 & 5.7 & 11.72 & 26.02 \\
\hline 9 & 2.54 & 2.85 & 7.52 & 9.62 & 33.54 \\
\hline 10 & & 2.88 & & & \\
\hline 11 & & 3.88 & & & \\
\hline Average WPI & $\mathbf{3 . 1 4}$ & $\mathbf{3 . 4 0}$ & $\mathbf{6 . 7 1}$ & $\mathbf{9 . 2 5}$ & $\mathbf{2 8 . 0 8}$ \\
\hline
\end{tabular}

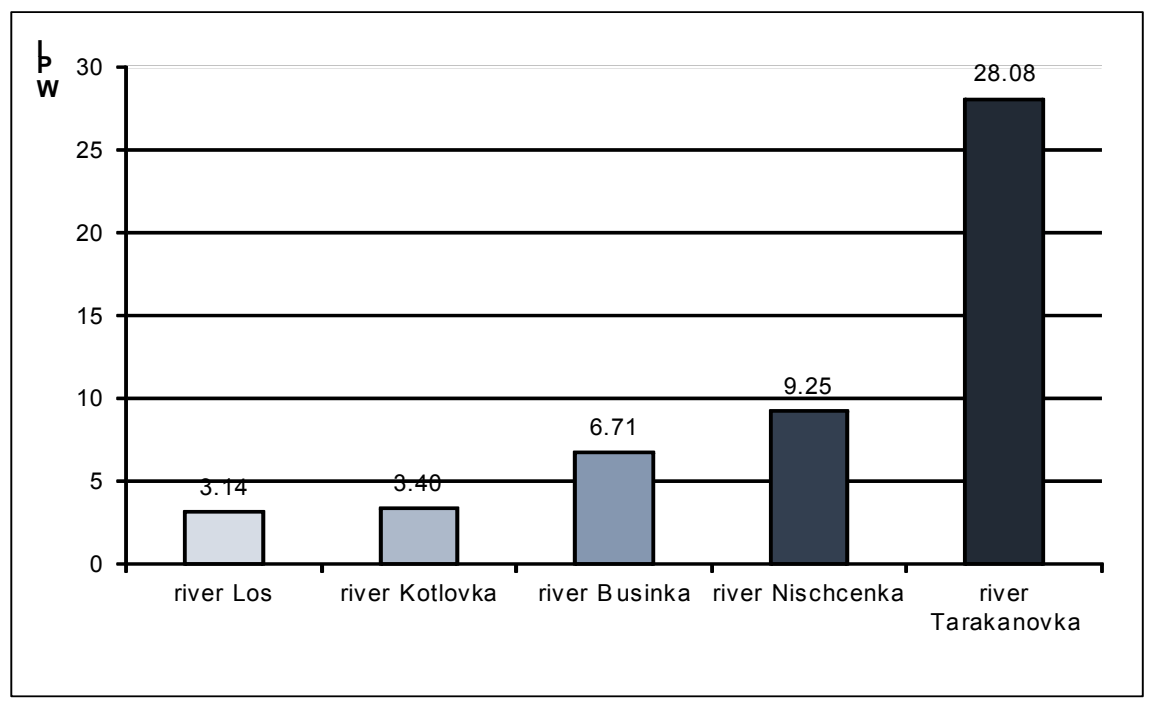

Figure 1: The average WPI in Moscow's small rivers.

\subsection{Results of BAC calculation}

BAC is used for assessment of water body contamination. It is calculated by the following formula [10]:

$$
\mathrm{BAC}=\mathrm{C}_{\mathrm{BS}} / \mathrm{C}_{\mathrm{water}}
$$


where $C_{B S}$ - the concentration of pollutant in the bottom sediments sample, $C_{\text {water }}$ - concentration of pollutant in the water sample with samples being taken from one sampling point.

Since the same value of BAC can fit different situations prevailing in the water body, depending on the absolute concentrations of the substance in water and bottom sediments (taking into account existing standards - MPC, background concentrations), the degree of contamination of the water body proposed to estimate as follows (Table 7):

Table 7: BAC contamination assessment of water body.

\begin{tabular}{|c|l|}
\hline BAC value $(\mathrm{n}=1-9)$ & \multicolumn{1}{|c|}{ Characteristics of water body } \\
\hline $\mathrm{n} * 10$ & $\begin{array}{l}\text { Relatively satisfactory condition with low concentrations of } \\
\text { pollutants in water and sediments (with no signs of chronic } \\
\text { contamination) }\end{array}$ \\
\hline $\mathrm{n} * 10-\mathrm{n} * 10^{2}$ & $\begin{array}{l}\text { Income of fresh contamination to water body (elevated } \\
\text { concentrations in water samples) }\end{array}$ \\
\hline $\mathrm{n} * 10^{3}-\mathrm{n} * 10^{4}$ & $\begin{array}{l}\text { High levels of chronic pollution of the water body (with } \\
\text { concentrations of pollutants in water, substantially exceeding } \\
\text { MPC). }\end{array}$ \\
\hline
\end{tabular}

$\mathrm{BAC}$ were calculated for $\mathrm{Cu}$ and $\mathrm{Zn}$. BAC calculation results are presented in table 8 .

Based on the data presented in the table, as well as the data on heavy metal pollution of the water and bottom sediments of these rivers, we can say that the Rivers Businka and Nischcenka have chronic high levels of heavy metal contamination. Low values for BAC in River Tarakanovka are due to high concentrations of heavy metals in the water samples of the river, which can be caused by fresh contamination. The same conclusions hold for the low values of BAC in Los River, taking into account, however, much less contamination of the river. River Kotlovka has high BAC levels, however, unlike Rivers Businka and Nischcenka, the concentration of heavy metals in water and sediments of the river are low.

\section{Conclusion}

In this work we observed the water pollution of Moscow urban rivers with different levels of anthropogenic impact: Los, Kotlovka, Businka, Tarakanovka and Nischcenka.

The results of water samples analyses show that the most polluted river is River Tarakanovka with the basic pollutants being heavy metals, namely, the total $\mathrm{Fe}, \mathrm{Cu}$ and $\mathrm{Zn}$. The water of Rivers Businka and Nischcenka is also heavily polluted, especially with organic substances. Rivers Los and Kotlovka are also polluted by heavy metals, though they flow in relatively clean territories. 


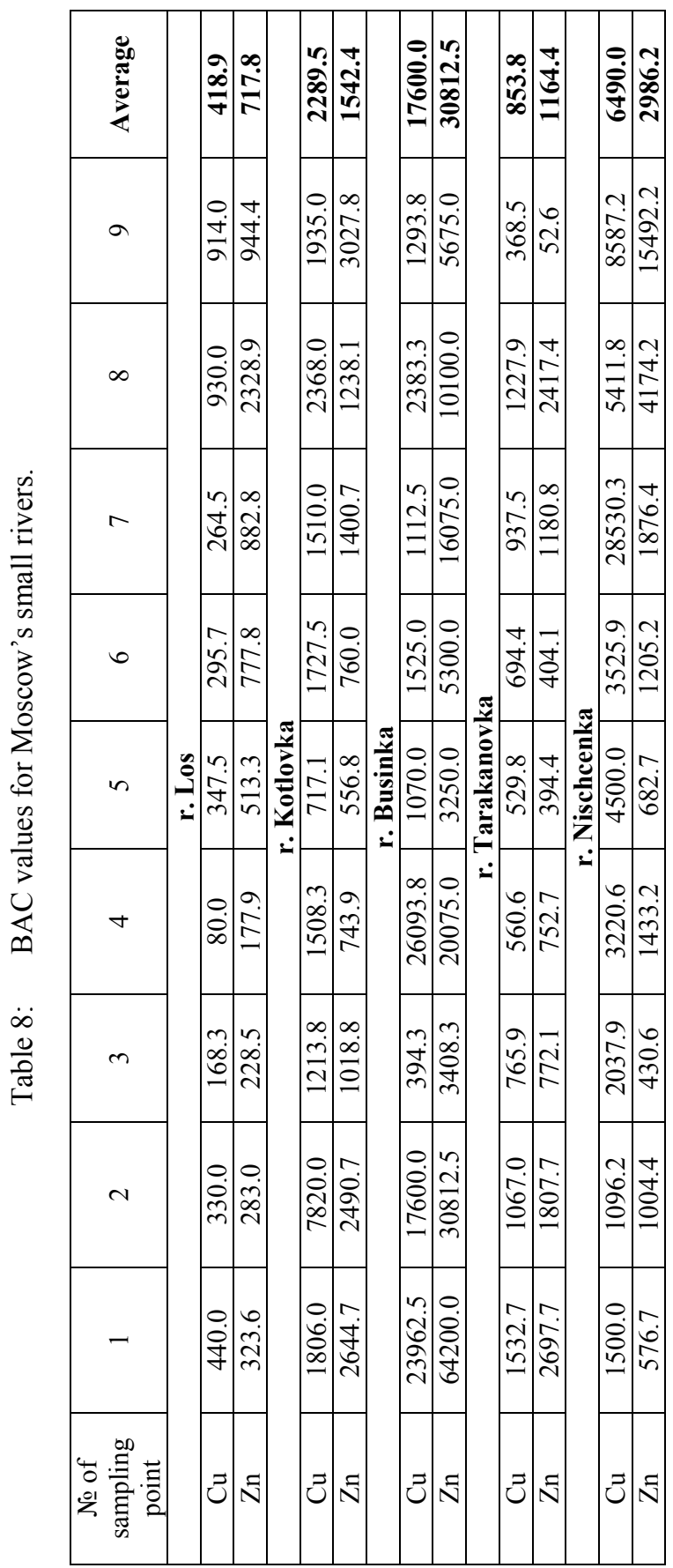


The assessment of water quality with WPI shows that Rivers Los and Kotlovka have a water quality class $3 b$ - "very contaminated". The water of River Businka is characterized by a quality class $4 \mathrm{~b}$ - "dirty", the water of River Nischcenka - by a quality class $4 \mathrm{c}$ - "very dirty". The most polluted water is in River Tarakanovka. It is characterized by a quality class 5 - "extremely dirty".

According to BAC calculation, Rivers Businka and Nischcenka have high levels of chronic contamination. In Rivers Tarakanovka and Los, a fresh income of pollutants is possible due to low BAC and relatively high concentrations of pollutants in water samples. River Kotlovka has high BAC but no chronic contamination occurs.

\section{References}

[1] Voronin A.V., Kiseleva S.P., Rykov S.V., Ecologicheskie problemy ispolzovaniya malyh rek (Ecological problems of small rivers' usage), Journal of Russian Nations Friendship University, Series "Ecology and security”, №3, pp. 74-77.

[2] Golubchikov S.N., Malye reki kak indicator vodopolzovaniya (Small rivers as indicator of water usage), Energy, 2005, №1, pp. 56-60.

[3] Goruynova S.V. Vliyanie antropogennogo vozdeistviya na ecologicheskoe sostoyanie maloi reki (Influence of anthropogenic impact on ecological condition of small river), Journal of Moscow State Pedagogical University, Series “Natural sciences”, 2010, №2, pp. 57-64.

[4] Trifonova T.A., Senatov A.S. Otsenka predelno dopustimoy technogennoy nagruzki na vodotoki malogo rechnogo basseina (Assessment of maximum permissible technological impact on watercourses of small river basin), Engineering geology, 2004, №4, pp. 322-330.

[5] Doklad o sostoyanii okruzhayuschcei sredy v gorode Moskva v 2012 godu (Report for environmental condition in Moscow for year 2012). Moscow government, department of nature management and environmental protection, Moscow, 2013.

[6] Moscow agency for ecological monitoring. http://www.mosecom.ru /water/quality/.

[7] Federal Centre for analysis and evaluation of the technogenic impact. www.fcao.ru.

[8] Russian Federation State Committee for Fisheries decree №20 from $18^{\text {th }}$ January 2010 "On approval of water quality standards for fishery water bodies, including standards of maximum permissible concentrations of harmful substances in the waters of fishery water bodies"

[9] GD 52.24.643-2002 "Metod kompleksnoi otsenki stepeni zagryaznennosti poverhnostnyh vod po gidrochimicheskim pokazatelyam (Method of complex assessment of surface water pollution by hydrochemical parameters)".

[10] Nikanorov A.M., Stradomskaya A.G., Chronisheskoe zagryaznenie presnovodny obiektov (Chronic contamination of freshwater objects), Water resources, 2007, 34, №3, pp. 337-344. 